\title{
Religious Education Policy in Public Schools During the New Order
}

\author{
Mohammad Kosim \\ Institut Agama Islam Negeri Madura \\ email: kosim@iainmadura.ac.id
}

\begin{abstract}
The new order government policy about religious education in state schools gradually led to an accommodative policy. If the old order government made religious education a facultative subject, then at the beginning of the new order the government strengthened the position of religious education by removing facultative provisions, even though they were not obligatory. Until finally, through Law number 2 (1989), the government required religious education to be taught in all channels, types, and levels of education. And the right of every student to get religious lessons by their religion and is taught by religious educators. This research includes historical research and policy studies, because it relies on past data, whose steps consist of four main activities, namely heuristics, verification, interpretation, and historiography. This accommodative policy is influenced by several factors, including; the government's determination to implement Pancasila purely and consistently after it was diverted in the old order era; the weakening of the government's power at that time so that it required the political support of muslims as the majority population; There is an intellectual transformation of muslim thinkers and political activists towards harmonious and complementary political relations between Islam and the state so that Islamic ideas are more easily accepted; and muslims experience a process of rapid social, educational, economic and political mobilization and so that more and more people are involved in government and can influence policies in a pro-muslim direction.

[Kebijakan pemerintah orde baru terkait pendidikan agama di sekolah negeri, secara bertahap mengarah pada kebijakan akomodatif. Jika
\end{abstract}

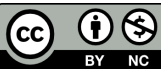

DOI: 10.19105/karsa.v28i2.3936 
pemerintah Orde Lama menjadikan pendidikan agama sebagai mata pelajaran fakultatif, maka di awal Orde Baru pemerintah memperkuat kedudukan pendidikan agama dengan menghapus ketentuan fakultatif, kendati belum mewajibkan. Hingga akhirnya, melalui Undang-Undang Nomor 2 Tahun 1989, pemerintah mewajibkan pendidikan agama diajarkan di semua jalur, jenis, dan jenjang pendidikan. Dan hak setiap peserta didik untuk mendapatkan pelajaran agama sesuai dengan agama yang dianut, dan diajarkan oleh pendidik seagama. Penelitian ini termasuk dalam penelitian sejarah dan studi kebijakan, karena bertumpu pada data masa lalu yang tahapannya terdiri atas empat kegiatan utama yaitu: heuristik, verifikasi, interpretasi, dan historiografi. Kebijakan akomodatif tersebut dipengaruhi beberapa faktor, antara lain: tekad pemerintah untuk melaksanakan Pancasila secara murni dan konsekuen setelah diselewengkan di era Orde Lama; melemahnya kekuatan pemerintah saat itu sehingga membutuhkan dukungan politik umat Islam sebagai penduduk mayoritas; transformasi intelektual pemikir dan aktivis politik muslim ke arah hubungan politik yang harmonis serta saling melengkapi antara Islam dan negara, sehingga gagasan Islam lebih mudah diterima; dan umat Islam mengalami proses mobilisasi sosial, pendidikan, ekonomi dan politik yang cepat, sehingga semakin banyak yang terlibat dalam pemerintahan dan dapat mempengaruhi kebijakan ke arah yang berpihak kepada umat Islam.]

Keywords: policy, old order, new order, school, religious education

\section{Introduction}

The founders of this nation were well aware of the importance of religion in building the nation and state, so that "God Almighty" was positioned as the first precept in Pancasila, the foundation of the state. In other words, the founders of this nation aspire to have the people who inhabit this country be a religious nation. Having religious ideals does not mean that Indonesia will become a religious country. However, Indonesia is also not called a secular state because Pancasila, with its first precepts, shows the partisanship of the state towards religion and its adherents. Therefore, according to Mahfud MD, Indonesia is more

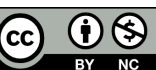

DOI: $10.19105 /$ karsa.v28i2.3936 
accurately called a religious national state. ${ }^{1}$ With the principle of "God Almighty" the state must be present and active in building a religious nation. The presence of the state is manifested in policies that make it easier for the nation's children to get religious education through all educational channels, especially formal education in public schools.

In reality, since Indonesia's independence until now, government policies in positioning religious education in public schools are quite diverse. In the old order era, religious education was only used as a facultative subject that did which did not affect class advancement or graduation, so parents or adult students may not take religious lessons. ${ }^{2}$ Course many factors influence this policy, especially because of the weak political power of Muslims in parliament and government so that they fail to fight for religious education as a compulsory subject in public schools. ${ }^{3}$ Apart from the influencing factors, what is clear is that the policy is not in line with the basic state of Pancasila which positions "God Almighty" in the first and foremost principles.

If the old order government had not fully supported the strengthening of religious education in schools, what about the new order government policies, and what factors influenced this policy? These questions are to be answered through this research. As far as researchers know, this problem has not been studied much. If anything, the focus is somewhat different from this study. For example, Abd. Rahman Assegaf ${ }^{4}$ examines the position of Islamic Religious Education (PAI) in the constellation of national education in the colonial era to the era of independence, the pattern of institutional development and the

\footnotetext{
${ }^{1}$ Mahfud MD, “Indonesia Bukan Negara Sekuler Juga Negara Agama,” Republik Merdeka, March 18, 2013, http://polhukam.rmol.co/read/2013/03/18/102774/MahfudMD:-Indonesia-Bukan-Negara-Sekuler-Juga-Negara-Agama.

${ }^{2}$ Luthfi Khairul Fikri, Munawar Rahmat, and Wahyu Wibisana "Perkembangan Pendidikan Agama Islam di Sekolah Dasar Tahun 1945-1966," Tarbawy: Indonesian Journal of Islamic Education 1, no. 1 (2014): 44-52, https://ejournal.upi.edu/index. $\mathrm{php} /$ tarbawy/article/view/3760/2679.

${ }^{3}$ Mohammad Kosim, "Kebijakan Pendidikan Agama Islam di Sekolah pada Masa Orde Lama," Karsa: Jurnal Sosial dan Budaya Keislaman 22, no. 21 (2014): 1-20, http://ejournal.iainmadura.ac.id/index.php/karsa/article/view/550.

${ }^{4}$ Abd. Rahman Assegaf, Politik Pendidikan Nasional: Pergeseran Kebijakan Pendidikan Agama Islam dari Proklamasi ke Reformasi (Yogyakarta: Kalam Mulia, 2005).
}

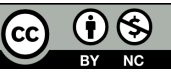


PAI curriculum, community responses regarding PAI policies by the government, and themes that need attention for efforts to reorient PAI insights to be more contextual and relevant to contemporary issues.

Likewise, a study conducted by M. Saerozi ${ }^{5}$ attempted to trace the pattern of religious education prevailing in Indonesia, the pattern of political policies behind the formation of confessional religious education, as well as forms of religious education policies that are relevant to the reality of religious pluralism in Indonesia.

Alrudin Yansah also studied government policies towards Islamic Religious Education in the new order era, but in conclusion, he did not mention the stages of the new order government policies related to religious education in schools. ${ }^{6}$ Heni Yuningsih ${ }^{7}$ also researched Islamic education policies in the new order era, but in conclusion, it was more pertinent to the joint decision of three Ministers which had a positive impact on madrasahs. Tasman Hamami ${ }^{8}$ also studied Islamic Religious Education in schools as a historical necessity, which in his conclusion states that Islamic Religious Education in public schools is a historical imperative that is parallel to other educational content. However, his study did not mention specifically the religious education policy in the new order era and the factors that influenced it.

\section{Methods}

\footnotetext{
${ }^{5}$ M. Saerozi, Politik Pendidikan Agama dalam Era Pluralisme (Yogyakarta: Tiara Wacana, 2007).

${ }^{6}$ Alrudy Yansah, "Politik Kebijakan Pemerintah terhadap Pendidikan Agama Islam di Masa Orde Baru," Nur El-Islam: Jurnal Pendidikan dan Sosial Keagamaan 3, no. 1 (2016): 50-62, https://ejurnal.iaiyasnibungo.ac.id/index.php/nurelislam/article/view/ 32.

${ }^{7}$ Heni Yuningsih, "Kebijakan Pendidikan Islam Masa Orde Baru," Tarbiya: Jurnal Ilmu Pendidikan Islam 1, no. 1 (2015): 175-94, https://journal.uinsgd.ac.id/index. php/jurnal-tarbiya/article/view/142.

${ }^{8}$ Tasman Hamami, "Pendidikan Agama Islam di Sekolah Umum sebagai Keharusan Sejarah," Pendidikan Agama Islam 1, no. 2 (2004): 171-91, http://digilib.uinsuka.ac.id/8665/.
}

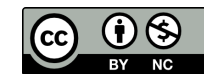

DOI: $10.19105 /$ karsa.v28i2.3936 
This research includes historical research and policy studies. Historical because it relies on past data, ${ }^{9}$ whose steps consist of four main activities, namely heuristics, verification, interpretation, and historiography. ${ }^{10}$ It is called a policy study because what it examines is government policies related to religious education in public schools. ${ }^{11}$

Sources of data in this study include primary and secondary data. Primary data is in the form of copies of government decisions such as the Decree of the People's Consultative Assembly (MPR), laws, government regulations, and other policy products related to religious education in schools during the new order era. Secondary data is in the form of information in books, magazines, bulletins, statements, and news broadcast through the media related to this topic. To determine the weight of documentary data, internal and external criticisms were used. Internal criticism seeks to understand the relevance of data to the research focus, while external criticism seeks to determine the authenticity of the data. ${ }^{12}$ Collecting data using the documentation method with research instruments in the form of documentation guidelines. Data analysis was carried out during and after the research took place using the document analysis method.

\section{Results}

The new order government was a continuation of the old order government. The terms "old" and "new" are not just differences in time but most importantly are differences in ideology. The old order government, especially in the last years of government, was seen as having deviated from the Pancasila ideology. Meanwhile, the new order attempted to straighten out these deviations with an initial determination to implement the Pancasila ideology purely and consistently in the life of the state and nation. The political crisis after the failure of the military

\footnotetext{
${ }^{9}$ Gottschalk Louis, Mengerti Sejarah, trans. Nugroho Notosusanto (Yogyakarta: ArRuzz Media, 2006), 39.

${ }^{10}$ Notosusanto Nugroho, Norma-Norma Dasar Penelitian dan Penulisan Sejarah (Jakarta: Pusat Sejarah ABRI, 1974), 17.

${ }^{11}$ Sugiyono, Metode Penelitian Kebijakan, Pendekatan Kuantitatif, Kualitatif Kombinasi, $R \& D$ dan Penelitian Evaluasi (Bandung: Alfabeta, 2017).

${ }^{12}$ Dudung Abdurahman, Metodologi Penelitian Sejarah (Yogyakarta: Ar-Ruzz Media, 2007), 67-73.
} 
coup masterminded by the Indonesian Communist Party (PKI) on September 30, 1965, made the country's situation even more unstable. Soekarno's reluctance to disband the PKI gave rise to a leadership crisis. The people increasingly did not believe in Soekarno. The peak of this distrust was a massive demonstration led by students on January 10, 1966, with the theme TRITURA (Three People's Demands), namely dissolving the PKI, clearing the Dwikora Cabinet from PKI elements, and lowering prices, and improving the economy.

After the TRITURA action, the condition of the country became more and more uncertain which then forced President Soekarno to issue President Soekarno's Order dated March 11, 1966, known as Super Semar, which contained President Soekarno's order to Lt. Gen. Soeharto, as Commander of the Army on behalf of the President to (1) take everything measures deemed necessary to ensure the security and order and stability of the course of the revolution; (2) Ensuring personal safety and the dignity of the President/Supreme Commander/Great Leader of the Revolution; and (3) Carry out with certainty all the teachings of the Great Leader of the Revolution. ${ }^{13}$

The release of Super Semar is often referred to as the initial momentum for the birth of the new order. Armed with this Super Semar, the Minister/Commander of the Army, Lt. Gen. Soeharto, on March 12, 1966, issued a Presidential Decree/Supreme Commander number $1 / 3 / 1966$ regarding the dissolution of the PKI. Soeharto's success in quelling the PKI made his name even more popular in the eyes of the people, and on the other hand, Soekarno's big-name became increasingly popular. Since October 1, 1965, there was a dualism of national leadership between Soekarno and Soeharto. This condition makes the domestic situation increasingly threatened by civil war. Finally, on March 12, 1966, the MPRS (Provisional People's Consultative Assembly) issued MPRS Decree Number XXXIII/MPRS/1967 by appointing Soeharto as Acting President and dismissing Soekarno from the position of President. One year later the

\footnotetext{
${ }^{13}$ Taufik Abdullah, AB Lapian, and Abdul Syukur, "Indonesia dalam Arus Sejarah: Orde Baru dan Reformasi (Jilid 8)," Indonesia dalam Arus Sejarah: Orde Baru dan Reformasi (Jakarta: Ichtiar Baru Van Hoeve, 2013), 55-57.
}

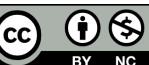

DOI: $10.19105 /$ karsa.v28i2.3936 
MPRS issued MPRS Decree Number XLIV/MPRS/1968 which officially dismissed Soekarno from his position as President and officially appointed Suharto as President with the main task of holding General Elections as soon as possible.

The first election was held in 1971 with Golkar as the winner, which subsequently led Suharto to become the President's choice of the people (through the MPR) after he was appointed President by the MPRS in 1968. Subsequent elections (1977, 1982, 1987, 1992 and, 1997) were always won by Golkar, and automatically Suharto, who was always nominated as President, always won. Until finally Soeharto resigned from his position on May 21, 1998, after a prolonged political crisis and leadership. The end of Soeharto's leadership for approximately thirty years at the same time ended the New Order regime with all its advantages and disadvantages. In a long period time (19661998) the new order government had made many policies in regulating religious education lessons in public schools. The policy referred to is contained in the MPRS Decree Number XXVII/MPRS/1966 concerning Religion, Education, and Culture. Several articles in this chapter regulate religious education in schools, namely Chapter I (on Religion) article 1 "Making religious education a subject in schools from elementary schools to state universities". Chapter II (concerning Education) article 3 states "Education aim is to form a true Pancasila human being based on the provisions as desired by the Preamble to the 1945 Constitution and the contents of the 1945 Constitution".

The above provisions are proof that the new order government was determined to implement Pancasila purely and consistently, which was shown with the aim of education "forming true Pancasila people" and the implementation of religious education in schools and colleges. Even though it has not been determined as a compulsory subject, the elimination of the sentence " ... with the understanding that students have the right not to participate, if the guardian of the student/adult student expresses their objection" as in MPRS Decree Number II/MPRS/1960, a product of the old order regime, shows that the new order regime has paid more attention to the importance of religious education in schools, so there is no reason for students not to attend religious lessons in schools. As it is understood that the fatal mistake of the old order regime was an ideological aberration; from the Pancasila

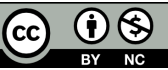

DOI: $10.19105 /$ karsa.v28i2.3936 
ideology to the socialist-communist ideology so that it tends to deny the existence of religious education in schools. Evidently, during the old order, religious education in schools had a very weak position, only becoming a facultative subject so that parents or adult students could choose whether or not to take religious subjects

Following up on the 1966 MPRS Decree, especially regarding the implementation of religious education in schools, a Joint Regulation of the Minister of Education and Culture \& the Minister of Religion was made on 23 October 1967, which contained: Class I-II SD are given religious subjects 2 hours per week, class III 3 hours per week, and class IV and above 4 hours per week. This also applies in junior high and high school. Meanwhile, in college, it is given 2 hours per week. ${ }^{14}$ Also, the 1968 Curriculum was compiled by dividing subjects into three groups, namely (1) the Pancasila Spirit Development Group; (2) Basic Knowledge Development Group; and (3) the Special Skills Development Group. Religious Education subjects are included in the first group along with Citizenship Education, Indonesian Language, and Sports. Religious Education lesson hours (especially in SMA) are set; class I 3 hours per week, class II 3 hours per week, and class III 3 hours per week.

The placement of religious subjects into the Pancasila Soul Development subject group together with the Citizenship Education subject shows the government's awareness that to form a true Pancasila spirit must be through religious education. Ignoring religious education means neglecting the realization of citizens with Pancasila. Furthermore, the 1966 MPRS decree was strengthened by the MPR Decree Number IV/MPR/1973 concerning State Policy Guidelines (GBHN), in which several articles are regulating religious education in schools, particularly in Chapter IV regarding the Five-Year Development General Scheme. Second, in the Field of Religion and Belief in Almighty God, Socio-Culture, it is stated in point b as follows: "b) Efforts will be made to increase the facilities necessary for the development of religious life and belief in God Almighty, including

\footnotetext{
${ }^{14}$ Karel A Steenbrink, Pesantren Madrasah Sekolah: Pendidikan Islam dalam Kurun Modern (Jakarta: LP3ES, 1994), 94.
}

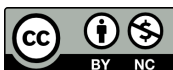

DOI: $10.19105 /$ karsa.v28i2.3936 
religious education that is included in the curriculum in public schools, from elementary schools to state universities."

Based on the 1973 MPRS decree, the government issued Kurikulum 1975. In this new curriculum (especially those applicable in SMA), subjects were grouped into three programs: (1) General Education Program; (2) Academic Education Program; and (3) Vocational Education Program. Religious Education is included in the first group along with the subjects of Pancasila Moral Education, Sports and Health Education, and Arts Education. Religious Education lesson hours are set at 2 hours (45 minutes) per semester for 6 semesters.

Furthermore, the 1973 MPR decrees were consecutively strengthened by the MPR Decree Number IV/MPR/1978 concerning State Policy Guidelines (GBHN), MPR Decree Number II/MPR/1983 concerning GBHN, and MPR Decree Number II/MPR/1988 concerning GBHN. Until the birth of Law Number 2 of 1989 concerning the National Education System (passed on March 27, 1989, by President Soeharto), which requires religious education to be taught in schools. This is the first law on national education produced by the new order regime.

In this law there are a number of articles that are specifically related to religious education in schools, namely: a) Article 4: National Education aims to educate the nation's life and develop Indonesian people as a whole, namely humans who believe and have faith in God Almighty and have high moral character, have knowledge and skills, physical and spiritual health, a solid and independent personality and a sense of social and national responsibility "; b) Article 39 paragraph (2): The content of the curriculum for each type, path and level of education must include (a) Pancasila education, (b) Religion education, and (c) Citizenship education; c) Elucidation of article 39 paragraph (2): Religious education is an effort to strengthen faith and devotion to God Almighty in accordance with the religion adhered to by the students concerned by paying attention to the demand for respect for other religions in the relationship of harmony between religious communities in society for realizing national unity; d) Article 28 paragraph (2): In order to be appointed as teaching staff, the teaching staff concerned must have faith and fear God Almighty, have an insight into Pancasila and the 1945 Constitution and have qualifications as teaching staff; e)

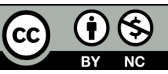

DOI: 10.19105/karsa.v28i2.3936 
Elucidation of article 28 paragraph (2): Religious education teaching staff must have a religion in accordance with the religion taught and the religion of the student concerned.

It is clear in this law that religious education is a compulsory subject in all paths, types, and levels of education. The term "mandatory" was only discovered in this education law. Previously, from the era of the old order until before this law was passed, the term "obligatory" was only a struggle for Muslims. In subsequent developments, the existence of Law Number 2 of 1989 was strengthened through the MPR Decree Number II/MPR/1998 concerning GBHN.

The follow-up to the issuance of Law Number 2 of 1989, the government issued Curriculum 1994. In this curriculum, especially those that apply in Senior High School (SMA), subjects are grouped into two programs; general teaching and special teaching programs. Religious Education subjects are included in the general teaching program which includes: Pancasila and Civic Education, Religious Education, Indonesian Language and Literature, National History and General History, English, Physical Education and Health, Mathematics, Science, Social Sciences, Arts Education. Religious Education subjects are taught in grades 1, 2, 3. A maximum of 2 hours per week (@45 minutes.

Although gradually and steadily government policies have led to accommodative policies by requiring religious education lessons in schools, at the historical practical level it has been colored by government policies that have created an impression of mutual suspicion between Muslims and the government. This is for example shown by the issuance of the Decree of the Minister of Education \& Culture Number 0211/U/1978 (when he was Daoed Joesoef) regarding the School Academic Year System which, among other things, set the month of Ramadan as a study time. This decision caused controversy because it was different from the previous tradition which stipulated the fasting month as a month-long holiday, thus provoking a strong reaction against the Muslim community in various regions on a national scale. ${ }^{15}$

\footnotetext{
${ }^{15}$ Amalia Solihat, Abdul Syukur, and Kurniawati "Kebijakan Kontroversial Menteri Daoed Yoesoef 1978-1983: Perubahan Tahun Ajaran dan Libur Bulan Ramadhan,"
}

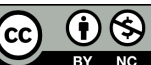

DOI: $10.19105 /$ karsa.v28i2.3936 
Another controversial policy that drew strong protests from Muslims during the new order era was the issuance of the Decree of the Director-General of Primary and Secondary Education Number 052/C/ Kep/D/1982 concerning Guidelines for School Uniforms on March 17, 1982 (signed by Darji Darmodihardjo). Among the contents of the decree, especially in Chapter IV article 5 paragraph (4): is "For schools which are related to religious considerations and local customs, they require different types and forms, especially for the type of clothing. princess then can wear a typical uniform for all students in one school. The difference lies in; a) typical headgear; b) the length of the sleeve of the blouse; 3) the length of the skirt. Furthermore, in Chapter VIII, Article 13 states "The daily uniform of a woman says: blouse, regular shape, wearing buttons, a schiller collar, short sleeves wearing one pocket without a cap on the left of the chest, white color, blouse worn under the skirt, skirt with one front stoplooi, zippers in the back, one hidden pocket on the left side, a waistband is provided on the waist, skirt five centimeters below the knee in gray color. One point fivecentimeters wide belt, black color, white short socks, women's shoes, closed low shape (with or without shoelaces), low heel, black, leather or fabric.

The Director-General's decision above received a strong reaction from the Muslim community because it seemed to prohibit Muslim female students from wearing the headscarf to school, which at that time the enthusiasm of students was getting higher in veiling. In the decree, no sentence that explicitly prohibits Muslim female students from wearing the headscarf, but the tough requirements for wearing the headscarf - because it has to be followed by all students in one school so that it is almost impossible for Muslim female students to wear school uniforms in any other form. This government policy immediately clashed with the desire of some muslim female students in state schools to cover their genitals by following the Islamic law that they believed in. All the more so because after the issuance of the decision, more and more students in headscarves received reprimands, prohibitions, and pressure from the school in various forms, from being summoned by the

Jurnal Pendidikan Sejarah 9, no. 1 (2020): 55-73, http://journal.unj.ac.id/unj/ index.php/jps/article/view/15782. 
teacher assigned by the school to handle the problem or by the principal directly, being teased in front of the class or when the school ceremony took place, his parents called him, interrogated by the police, prohibited from participating in teaching and learning activities in class, were prohibited from entering the school grounds, until finally he was expelled from school. Students who insist on wearing the hijab in the school environment are welcome to leave the public school where they are studying and transfer to private schools. ${ }^{16}$

Finally, due to a large amount of pressure from the muslim community for the anti hijab policy, on 16 February 1991, the DirectorGeneral of Primary and Secondary Education Decree was issued regarding the Refinement of the Decree of the Director-General of Primary and Secondary Education Number 052/C/Kep/D.82 concerning Guidelines for School Uniforms Number 100/C/Kep/D/1991. In a decision signed by Hasan Walinono, the wish of the students to wear the hijab has been accommodated, complete with examples of pictures of his clothes. However, the term used in the decree remains "typical uniform", not a headscarf or woman in muslim clothes.

\section{Discussion}

Likewise, the passing of Law Number 2 of 1989 did not go smoothly. Starting from a long and fierce debate between adherents of religions, especially Islam and Christianity or government. several articles/problems that were debated when it was still the 1988 National Education System Bill (RUU), especially those related to religious education in schools, among others: ${ }^{17}$

First, the problem of national education goals. In article 4 of the 1988 Bill, the formulation of the goals of national education states "National Education aims to educate the nation's life and develop Indonesian people as a whole, namely people who are devout to God Almighty ...", without mentioning the word believe is contained in the

\footnotetext{
${ }^{16}$ Herlambang Saleh, "Jilbab sebagai Keyakinan: Sikap Siswa SMP Negeri 14 Jakarta terhadap Pelarangan Penggunaan Jilbab 1982-1991" (Skripsi: Universitas Indonesia, 2010), 1-61.

${ }^{17}$ Assegaf, Politik Pendidikan Nasional, 220-222
}

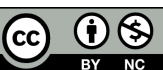

DOI: $10.19105 /$ karsa.v28i2.3936 
$1988 \mathrm{GBHN}$. According to Islamic groups, however, this formula has suffered a setback because previously in the MPR Decree Number II/MPR/1988 concerning GBHN - the term 'have faith and fear' has been used. Finally, after several discussions, the terms "faith and piety" were included in the formulation of national education goals.

Second, the problem of the religious education curriculum. Article 40 of the 1988 Bill states "The curriculum is prepared to realize national education by taking into account the stages of development of students and its suitability to the environment, technology, and arts, according to the type and level of each educational unit", without mentioning where the position of religious education is in the school curriculum. Then in the explanation of article 13 paragraph 1 of the 1988 Bill, it states "For this reason, basic education is held by providing education which includes, among other things, the growth of devotion to God Almighty, the building of character ..." This article does not provide certainty for the implementation of religious education in schools, because efforts to cultivate devotion to God Almighty can be included in other subjects such as PMP (Pancasila Moral Education).

The two articles above, according to the Islamic group, experienced tremendous setbacks, because the 1966 MPR Decree to the 1988 MPR Decree clearly states that religious education is included in the school curriculum, starting from elementary schools to universities. Even the Law on Education and Teaching in Schools Number 4 of 1950 in conjunction with Number 12 of 1954 also contains an article which states that religious education is taught in schools, even though it is still optional.

Third, regarding the authority of teachers as teachers of religious subjects. Initially, there was a heated debate between Islamic and Christian groups. The Islamic group requires that "a religious teacher must be religious by the religion taught and the religion of the student concerned". This proposal was strongly rejected by Christian groups because, in reality, many Muslim children were studying in Christian schools. So that if this proposal passes, Christian schools must bring in Islamic religious teachers to teach religion to Muslim children studying in Christian schools. As it is understood, Christian schools, apart from carrying out the mission of intellectual development, also have a hidden mission of Christianization through the educational institutions they

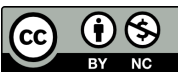

DOI: $10.19105 /$ karsa.v28i2.3936 
develop. As for Muslims, this proposal is very important to protect the belief of their children who have chosen a Christian institution as a place of learning. Also, religious education in Indonesia since the old order era has followed a confessional pattern, namely religious education which aims to develop the faith and piety of students according to the religion they adhere to. For this effort to be successful, religious lessons must be taught by teachers of the same religion as the learners' religions. Finally, the efforts of the Muslim community to pass the article were successful, although only in the explanation of Article 28 as quoted above.

The phenomenon above shows that the relationship between Islam and the state during the new order was not single, but varied, which Abdul Aziz Thaba mapped into three periods, namely the antagonistic period (1967-1982), the critical reciprocity (1982-1985), and the accommodative period (1985-1994). In the antagonistic era, the state had a hegemonic role while Muslims were at the periphery. Their relationship is full of conflict and mutual suspicion. During the critical reciprocal period, the antagonists are still visible but each party has started to lower its tension. The state began to view Muslims as the majority who had a big share in the development, while Muslims began to view the state in a non-confrontational position with them. Meanwhile, in the accommodative period, a mutually acceptable and mutually beneficial relationship began to exist between Muslims and the state. ${ }^{18}$

The explanation above also shows that the new order government policies about religious education in schools, although ultimately leading to mutually beneficial accommodative policies, were colored by conflict and tension as well as mutual suspicion between Muslims and the government. The cases of "not having school days off in the month of Ramadan" and "banning the headscarf" are examples that have become "spices" for conflict and mutual suspicion has been heating up. Likewise, the protracted government policy to oblige religious lessons in schools has made it difficult for Muslims to have a

\footnotetext{
${ }^{18}$ Abdul Azis Taba, Islam dan Negara dalam Politik Orde Baru (Jakarta: Gema Insani Press, 1996), 26-29.
}

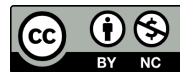

DOI: $10.19105 /$ karsa.v28i2.3936 
harmonious relationship with the government. Until finally the relationship between the two became harmonious with the issuance of Law Number 2 of 1989. The harmony of the Muslims with the government was further demonstrated by the launching of the Pesantren Kilat week by President Soeharto on June 14, 1996, to fill the long days off for school students. ${ }^{19}$ The mention of the term pesantren in the program is an indirect recognition of the importance of the pesantren education model in fostering the religious education of students.

The description above shows that the government policy of the new order in placing religious education in public schools gradually led to accommodative policies. Initially removing the facultative provisions as applied in the old order, although it was not mandatory until finally, religious education became a compulsory subject. Government policies that lead to accommodation are influenced by a number of factors, among others: ${ }^{20}$

First, the determination of the new order government to implement the Five Principles, with its five precepts, purely and consistently. Among the Pancasila principles that are directly related to religious education is the first principle of God Almighty. This first precept is not accidental to be in the first place, but philosophically this precept becomes spirit for the other four precepts. So that the second principle of "just and civilized humanity" should be just and civilized humanity based on the One Godhead. Likewise, the third principle "Unity of Indonesia", philosophically implies the meaning of Indonesian Unity based on One Godhead". Likewise the other two precepts.

The importance of the first principle as a pattern giver for the other four principles in Pancasila shows that Indonesia is not a secular

\footnotetext{
${ }^{19}$ Marwan Saridjo, Bunga Rampai Pendidikan Agama Islam (Jakarta: Amissco, 1990), 55.

${ }^{20}$ The factors that influence the policy can be collected from many sources, i.e.: Bahtiar Efendy, Islam dan Negara: Transformasi Pemikiran dan Praktik Politik Islam di Indonesia (Jakarta: Paramadina, 1998); Anas Saidi (ed), Menekuk Agama, Membangun Tahta; Kebijakan Agama Orde Baru (Jakarta: Desantara, 2004); Robert W. Hefner, Civil Islam; Islam dan Demokratisasi di Indonesia, terj. Ahmad Baso (Yogyakarta: LKiS, 2001); Zainuddin Maliki, Agama Rakyat Agama Penguasa (Yogyakarta: Yayasan Galang, 2000).
}

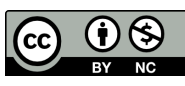


country that allows its citizens not to embrace religion. Likewise, with Pancasila as the basis of the state, Indonesia is also not a religious state as certain countries have made religion the basis of the state. Indonesia is a Pancasila country that obliges its citizens to embrace a certain religion according to their beliefs with the demand for mutual respect between the adherents of existing religions. Based on Pancasila, the state also strives for every Indonesian citizen to be a devout believer by the religion he believes. These efforts include the implementation of religious education in schools which is organized systematically in the form of programmed subjects. And students have no choice not to take religious lessons as experienced during the old order regime.

The government's determination at the beginning of the new order to implement Pancasila purely and consistently was in line with the spirit of the Muslims who were already very restless with the old communist-controlled regime which ignored the role of religion. Therefore, the similarity in principle between the government and Muslims smoothes the obligation of religious education in schools.

Second, the more appropriate government policies with the expectations of Muslims regarding religious education in schools cannot be separated from the desire of the authorities to get sympathy from the majority group (muslims). This phenomenon occurs in all regimes in power, from the old order, the new order to the reform order. During the old order era, this effort was made after the failure of Islamic groups to make Islam the basis of the state. So, to treat disappointment, the government made an accommodative policy by forming the Ministry of Religious Affairs. In the case of the new order, efforts to gain the sympathy of the muslim community were carried out intensely following the weakening of support for the president, especially from the military wing which, together with the bureaucracy in Golkar, became the backbone of the new order government. The passing of religious education as a compulsory subject (as mandated by Law Number 2 of 1989) is inseparable from President Soeharto's role in gaining the sympathy of Muslims.

In historical records, apart from the policy of religious education in schools, there were a number of other political policies that made the relationship between the new order government and Muslims more

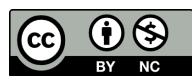

DOI: $10.19105 /$ karsa.v28i2.3936 
intimate, including the formation of the Amal Bhakti Muslim Pancasila Foundation in 1982, chaired by President Soeharto. Through this foundation, hundreds of mosques have been established in various regions and have sent preachers to various areas minus Muslims. Then the passing of Law Number 7 of 1989 concerning Religious Courts and the enactment of the Compilation of Islamic Law based on Presidential Instruction No.1 of 1991. Through these two provisions, Muslims are increasingly protected in carrying out Islamic teachings, especially in the field of marriage. Then the formation of ICMI (Indonesian Muslim Intellectuals Association) in 1990 in Malang which was attended by President Soeharto. Through this new platform, the longing of Muslim intellectuals in developing their ideas and actions is systematically accommodated, even though the existence of ICMI is getting dimmer along the way. Also the formation of BMI (Bank Muamalat Indonesia) in 1990. This institution became the forerunner to the proliferation of Islamic banking in various regions in Indonesia, so that Muslims are safer for Islamic-based economic activities.

Third, the intellectual transformation of a new generation of Muslim political thinkers and activists towards a harmonious and complementary political relationship between Islam and the state, so that the idea of Islam is more easily accepted. This is especially demonstrated by Nurcholish Madjid's idea of "Islam yes, Islamic party no". With this transformation of thought, the mutual suspicion between Muslims and the state can gradually be minimized and even turned into a relationship of mutual need. With this aim, this movement worked at various levels: (1) at the level of thought, they formulated a theological basis in line with their views on the relationship between Islam and the state; (2), at the level of social movements; and (3) at the level of government bureaucracy. Although these three movements are not related to each other, in reality, they complement each other. ${ }^{21}$

Fourth, Muslims have experienced a process of rapid social, educational, economic, and political mobilization as a result of the results of Indonesia's economic development under the new order

\footnotetext{
${ }^{21}$ Bahtiar Efendy, Hendro Prasetyo, and Arief Subhan, "Munawir Sjadzali, MA Pencairan Ketegangan Ideologis," in Menteri-Menteri Agama RI; Biografi SosialPolitik, ed. Azyumardi Azra and Saiful Umam (Jakarta: INIS-PPIM, 1998), 387-390.
} 
government and expanded access to higher modern education (at home and abroad). , so that more and more educated Muslims are involved in government. And through the government bureaucracy, they can play a real role in influencing policy towards the side of muslims.

\section{Conclusion}

The government policy of the new order in positioning religious education lessons in public schools gradually led to an accommodative policy. In the early days of the new order, the government established religious subjects as subjects from elementary school to university level. Although there is no compulsory term for participation, the absence of opportunities for parents and adult students to choose it has strengthened the position of religious education in schools. This is different from the old order period, which made religious lessons an optional subject so that parents of adult students could choose to take religious subjects or not. In subsequent developments, the position of the subject of religious education has become more stable, especially since the issuance of Law Number 2 of 1989 which stipulates religious education as a compulsory subject in every path, type, and level of education.

The factors that influenced the government policy of the new order in strengthening religious education as a compulsory subject in schools were: (1) There were a strong determination and enthusiasm for the new order regime to implement Pancasila as the basis of the state in a pure and consistent manner; (2) There is a desire of the authorities to get sympathy from the majority group (muslims) so that government policies are in favor of muslim; (3) There is an intellectual transformation of a new generation of Muslim political thinkers and activists towards harmonious and complementary political relations between Islam and the state so that Islamic ideas are more easily accepted. The relationship of mutual suspicion between the ummah and the state can gradually be minimized and even turned into a mutual need; (4) Muslims have experienced a process of rapid social, educational, economic, and political mobilization as a result of Indonesia's economic development under the new order government and expanded access to higher modern education; and through the government bureaucracy,

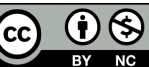

DOI: $10.19105 /$ karsa.v28i2.3936 
they can play a real role in influencing policies towards the side of muslims.

\section{Bibliography}

Abdullah, Taufik, AB Lapian, and Abdul Syukur. Indonesia dalam Arus Sejarah: Orde Baru dan Reformasi 8. Jakarta: Ichtiar Baru Van Hoeve, 2013.

Abdurahman, Dudung. Metodologi Penelitian Sejarah. Yogyakarta: ArRuzz Media, 2007.

Assegaf, Abd. Rahman. Politik Pendidikan Nasional: Pergeseran Kebijakan Pendidikan Agama Islam dari Proklamasi ke Reformasi. Yogyakarta: Kalam Mulia, 2005.

Bahtiar Efendy, Hendro Prasetyo, and Arief Subhan. "Munawir Sjadzali, MA Pencairan Ketegangan Ideologis." in MenteriMenteri Agama RI; Biografi Sosial-Politik, edited by Azyumardi Azra and Saiful Umam, 387-90. Jakarta: INIS-PPIM, 1998.

Efendy, Bahtiar. Islam dan Negara: Transformasi Pemikiran dan Praktik Politik Islam di Indonesia. Jakarta: Paramadina, 1998.

Gottschalk, Louis. Mengerti Sejarah, Translated by Nugroho Notosusanto. Yogyakarta: Ar-Ruzz Media, 2006.

Hamami, Tasman. "Pendidikan Agama Islam di Sekolah Umum sebagai Keharusan Sejarah." Pendidikan Agama Islam 1, no. 2 (2004): 171-91, http://digilib.uin-suka.ac.id/8665/.

Kosim, Mohammad. "Kebijakan Pendidikan Agama Islam di Sekolah pada Masa Orde Lama." Karsa: Jurnal Sosial dan Budaya Keislaman 22, no. 21 (2014): 1-20, http://ejournal.iainmadura. ac.id/index.php/karsa/article/view/550.

Luthfi Khairul Fikri, Munawar Rahmat, and Wahyu Wibisana "Perkembangan Pendidikan Agama Islam di Sekolah Dasar Tahun 1945-1966." Tarbawy: Indonesian Journal of Islamic Education 1, no. 1 (2014): 44-52. https://ejournal.upi.edu/index.php/tarba wy/article/view/3760/2679.

Mahfud MD, "Indonesia Bukan Negara Sekuler Juga Negara Agama." Republik Merdeka, March 18, 2013. http://polhukam.rmol.co/ $\mathrm{read} / 2013 / 03 / 18 / 102774 / \mathrm{Mahfud}-\mathrm{MD}$ :-Indonesia-Bukan-NegaraSekuler-Juga-Negara-Agama.

Notosusanto, Nugroho. Norma-Norma Dasar Penelitian dan Penulisan

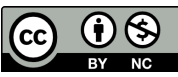


Sejarah. Jakarta: Pusat Sejarah ABRI, 1974.

Saerozi, M. Politik Pendidikan Agama dalam Era Pluralisme. Yogyakarta: Tiara Wacana, 2007.

Saidi, Anas (ed). Menekuk Agama, Membangun Tahta; Kebijakan Agama Orde Baru. Jakarta: Desantara, 2004.

Saleh, Herlambang. "Jilbab sebagai Keyakinan: Sikap Siswa SMP Negeri 14 Jakarta Terhadap Pelarangan Penggunaan Jilbab 19821991.” Skripsi: Universitas Indonesia, 2010.

Saridjo, Marwan. Bunga Rampai Pendidikan Agama Islam. Jakarta: Amissco, 1990.

Steenbrink, Karel A. Pesantren Madrasah Sekolah: Pendidikan Islam dalam Kurun Modern. Jakarta: LP3ES, 1994.

Solihat, Amalia, Abdul Syukur, and Kurniawati. "Kebijakan Kontroversial Menteri Daoed Yoesoef 1978-1983: Perubahan Tahun Ajaran dan Libur Bulan Ramadhan." Jurnal Pendidikan Sejarah 9, no. 1 (2020): 55-73. http://journal.unj.ac.id/unj/index. php/jps/article/view/15782.

Sugiyono. Metode Penelitian Kebijakan, Pendekatan Kuantitatif, Kualitatif Kombinasi, $R \& D$ dan Penelitian Evaluasi. Bandung: Alfabeta, 2017.

Taba, Abdul Azis. Islam dan Negara dalam Politik Orde Baru. Jakarta: Gema Insani Press, 1996.

Yansah, Alrudy. "Politik Kebijakan Pemerintah terhadap Pendidikan Agama Islam di Masa Orde Baru." Nur El-Islam: Jurnal Pendidikan dan Sosial Keagamaan 3, no. 1 (2016): 50-62. https:// ejurnal.iaiyasnibungo.ac.id/index.php/nurelislam/article/view/32. Yuningsih, Heni. "Kebijakan Pendidikan Islam Masa Orde Baru." Tarbiya: Jurnal Ilmu Pendidikan Islam 1, no. 1 (2015): 175-94. https://journal.uinsgd.ac.id/index.php/jurnaltarbiya/article/view/1 42.

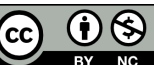

DOI: $10.19105 /$ karsa.v28i2.3936 